\title{
1 Impact of Environmental Values on the Breakeven Price of Switchgrass

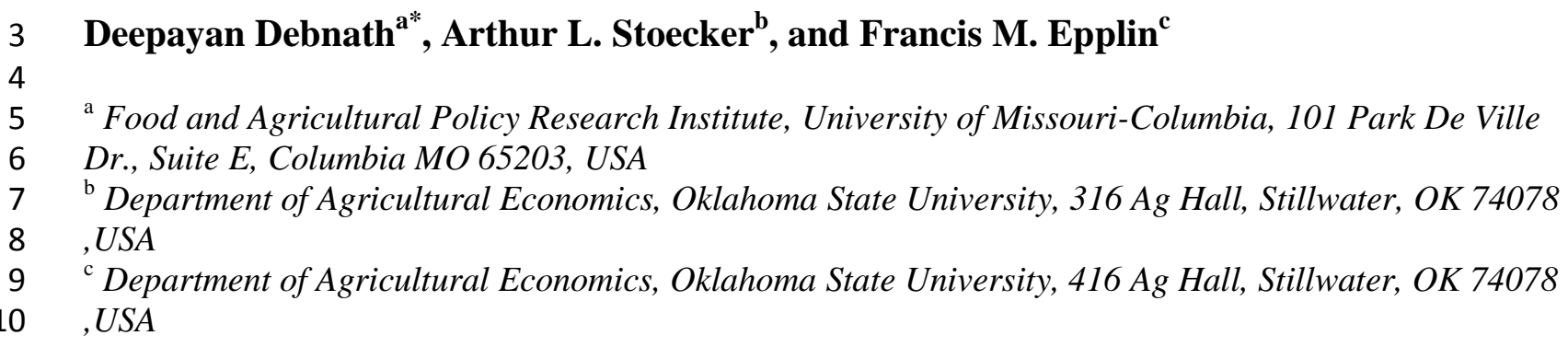

\section{ABSTRACT}

This study estimates the farm-gate breakeven price of switchgrass relative to wheat in external consequences are ignored and when the environmental costs of changes in soil erosion, fertilizer (nitrogen and phosphorous) runoff, and soil organic carbon (SOC) are considered. Results suggest that if indirect land use changes are ignored, the farm-gate breakeven price of switchgrass when only the internal costs are considered is $69 \%$ to $144 \%$ greater (depending on land quality) than if the value of selected external consequences are considered. The potential environmental benefits are greater if highly erodible land is switched from annual cropping to

22 switchgrass.

Key words: Agricultural runoff, farm-gate breakeven price, soil organic carbon (SOC), 


\section{Introduction}

With concern over environmental degradation there has been interest in finding alternative sources of energy across the globe. Part of this interest has focused on renewable

31 bioenergy, which is expected to have fewer negative environmental consequences than

32 hydrocarbon fuels. Among the many potential dedicated energy crops, switchgrass has

33 considerable promise due to its ability to grow on many different types of soil under diverse

34 climatic conditions. Switchgrass is a perennial native grass of North America, where it naturally

35 occurs over an area between $20^{\circ} \mathrm{N}$ to $55^{\circ} \mathrm{N}$ and $65^{\circ} \mathrm{W}$ to $98^{\circ} \mathrm{W}$. Switchgrass is a drought and

36 flood tolerant perennial lignocellulosic crop that can produce substantial biomass yields with

37 relatively little chemical fertilizer. As roots expand into the deep subsoil for nutrients and water,

38 switchgrass can deposit organic matter within the soil profile resulting in increasing the soil

39 organic matter. It also provides cover to the soil from the erosive force of wind and rain that

40 reduces erosion relative to continuous cropping with annual crops. There are additional

41 environmental benefits derived from reducing nitrogen and phosphorous runoff [1]. Since 1991

42 switchgrass production has received special attention in USA when the US Department of

43 Energy declared switchgrass as a model herbaceous energy crop [2].

Switchgrass has been evaluated as a potential biomass crop in several countries. Monti et

45 al. [3] did an economic feasibility study of switchgrass production under several scenarios in

46 Italy and found that the relative yield of switchgrass would have to be increased to enable it to

47 compete for land with maize and alfalfa. However, they did not consider the positive

48 environmental benefits derived from the switchgrass production. Smeets, Lewandowski and

49 Faaij [4] found that switchgrass was a promising bioenergy crop for the European Union mainly

50 because of yield, low production costs, and improved environmental outcomes relative to 
51 conventional crops. Samson and Omielan [5] concluded that in Canada switchgrass has

52 significant potential to be a feedstock for the cellulosic ethanol industry and could be a major

53 contributor in reducing Canadian $\mathrm{CO}_{2}$ emissions. Dam et al. [6] analyzed the environmental

54 impacts of large-scale biomass production from soybeans and switchgrass in Argentina. They

55 found that switchgrass accumulated more carbon than soybeans and resulted in lower soil loss.

56 They concluded that greatest potential environmental benefits could be achieved by producing

57 switchgrass on abandoned cropland. Ichizen et al. [7] and Ma et al. [8] showed that switchgrass

58 is effective in preventing soil erosion in one of the most arid region of the Loess Plateau in

59 China. The projected potential for switchgrass feedstock production raises several research

60 questions. First, what net price for switchgrass would be required to bid land from its current use

61 to switchgrass production? Second, what are the expected changes in soil erosion, fertilizer

62 (nitrogen and phosphorous) runoff, and soil organic carbon (SOC) from converting crop land

63 into switchgrass production, and what is the expected economic consequence of these changes?

64 In this research study, we estimate selected environmental benefits derived from the conversion

65 of land used to produce winter wheat for grain to the production of switchgrass biomass for

66 biorefinery feedstock.

67 The USA Environmental Protection Agency (EPA) using the Forestry and Agriculture

68 Optimization Model (FASOM) predicted that by 2022, it would be economically feasible to

69 produce $3.4 \times 10^{9} \mathrm{~m}^{3}$ of biofuel from switchgrass biomass feedstock [9]. The FASOM model

70 also projected that most of the switchgrass feedstock would be grown in Oklahoma replacing

71 wheat and hay production. Therefore, based on EPA's finding we consider Oklahoma as our

72 study region. 
Several studies have estimated the production costs of switchgrass biomass. Mooney et

74 al. [10] determined the breakeven price of switchgrass for four different locations in Tennessee.

75 They found that the farm-gate breakeven price of switchgrass based on 10-year production

76 contracts was $46 \$ \mathrm{Mg}^{-1}$ for an average yield of $17.7 \mathrm{Mg} \mathrm{ha}^{-1}$ and $69 \$ \mathrm{Mg}^{-1}$ for an average yield

77 of $8.5 \mathrm{Mg} \mathrm{ha}^{-1}$. Khanna et al. [11] estimated the Illinois farm-gate breakeven price of switchgrass

78 to be $98 \$ \mathrm{Mg}^{-1}$ with average yields of $9.42 \mathrm{Mg} \mathrm{ha}^{-1}$. Epplin et al. [12] found that under a land-

79 lease contract in Oklahoma, the estimated cost of switchgrass production was $41 \$ \mathrm{Mg}^{-1}$ under an

80 assumed eight-month harvest window. The cost increased to $58 \$ \mathrm{Mg}^{-1}$ when the harvest window

81 was restricted to two months per year. In Tennessee, based on farmer bids, the cost of producing

82 switchgrass ranged from $40 \$ \mathrm{Mg}^{-1}$ to $60 \$ \mathrm{Mg}^{-1}$ assuming that an average yield of $15.70 \mathrm{Mg} \mathrm{ha}^{-1}$

83 could be obtained. McLaughlin and Kszos [13] estimated USA farm-gate prices of switchgrass

84 of $30 \$ \mathrm{Mg}^{-1}$, and $44 \$ \mathrm{Mg}^{-1}$ for average yields of $11.4 \mathrm{Mg} \mathrm{ha}^{-1}$, and $9.4 \mathrm{Mg} \mathrm{ha}^{-1}$, respectively.

85 These studies did not consider the environmental consequences of producing switchgrass relative

86 to existing land use and also did not place any monetary value on those consequences while

87 estimating the farm-gate breakeven price of switchgrass.

Nelson et al. [14] discussed the environmental consequences of converting conventional crop land to switchgrass. They used the Soil and Water Assessment Tool (SWAT) watershed-

90 scale water quality model [15-17] to determine the environmental outcomes of switchgrass

91 production. They simulated switchgrass yields and other commodity crop yields and estimated

92 the farm-gate breakeven price of switchgrass. Graham et al. [18] used the Environmental Policy

93 Integrated Climate (EPIC) field-scale environmental model [19, 20] to predict switchgrass and

94 other alternative crop yields and their associated environmental outcomes. They determined the

95 farm-gate breakeven price of switchgrass by comparing it to the production of other alternative 
crops. Both of these studies found that switchgrass production reduced soil erosion and nutrient loss compared to annual crops. King et al. [21] also found that switchgrass production reduced soil erosion and nutrient loss. However, these studies did not attach any monetary value to the environmental benefits derived from converting to switchgrass production while estimating the farm-gate breakeven price of switchgrass. Production practices budgeted to estimate in the recognition that the environmental consequences of biomass production from a dedicated energy crop such as switchgrass would be locally specific to the region surrounding the biorefinery constructed to process the feedstock. In addition, the environmental consequences would differ depending on the quality of the land used for producing the biomass and on the current use of the land.

The primary objective of this study is to determine the site-specific farm-gate breakeven price of switchgrass for two situations: (1) when external consequences are ignored and (2) when the environment costs of changes in soil erosion, fertilizer (nitrogen and phosphorous) runoff, and SOC are considered. To achieve the objective it is necessary to estimate the expected yield of switchgrass and grain-only wheat and the expected differences in nitrogen loss, phosphorous loss, soil loss, and changes in SOC for alternative soil classes over a multi-county area.

The landowners' decision regarding shifting into a long-term investment such as switchgrass by replacing an existing annual crop depends on the relative expected returns. Since no formal market exists for switchgrass biomass, the opportunity cost of producing switchgrass is estimated from the returns of the best alternative crop, which is wheat in the study region. This study is divided into three sections: (1) the EPIC model, which was used to simulate the expected yield of switchgrass and wheat along with the environmental outcomes including (a) total soil loss $\left(\mathrm{Mg} \mathrm{ha}^{-1}\right),(\mathrm{b})$ nitrogen loss $\left(\mathrm{kg} \mathrm{ha}^{-1}\right)$, (c) phosphorous loss $\left(\mathrm{kg} \mathrm{ha}^{-1}\right)$, and (d) 
119 changes in SOC $\left(\mathrm{kg} \mathrm{ha}^{-1}\right)$; (2) an economic model, which was used to estimate the farm-gate

120 breakeven price of switchgrass when external consequences are ignored, and (3) the farm-gate

121 breakeven price of switchgrass, which was estimated as a function of the environmental costs of

122 soil erosion, fertilizer (nitrogen and phosphorous) runoff, and SOC depletion.

\section{$123 \quad 2 . \quad$ Materials and Methods}

This study examined switchgrass production in counties surrounding a hypothetical 125 potential biorefinery located near Okemah in Okfuskee County, Oklahoma. The site was chosen

126 because it is located near the geographical center of three of the biorefinery locations (Lincoln,

127 Hughes, and Muskogee counties) identified by the US-EPA [9].This potential biorefinery is

128 assumed to have an annual switchgrass feedstock requirement of 700,000 Mg. Debnath [22]

129 previously determined the location and land classes where land would optimally be leased. Farm130 gate breakeven prices were determined for each of these counties and land classes (Figure 1).

Data were obtained from several sources. Historical weather information was obtained

132 from National Oceanographic Atmospheric Association (NOAA) [23] and Mesonet [24]. The

133 quality of proposed land with land capability classifications of I, II, and III in each county was

134 determined from the USDA-NRCS Land Survey Geographic (SSURGO) database [25]. Land

135 classes greater than III have very severe limitations for crop production. Hence, the study was

136 limited to land capability classes I-III (land class I, II, and III). The land capability classification

137 is a system of grouping soils primarily on the basis of their capability to produce common

138 cultivated crops and pasture plants without deteriorating over a long period of time. A land

139 capability class within each county may include several soil series and types. Soils are classified

140 into series based on morphology and other characteristics such as color, texture, structure, and

141 mineral composition. Land classified as Class I in one region may not be nearly as productive as 
142 Class I land in another region. Universal Soil Loss Equation (USLE) related attributes for each

143 land class of each county was obtained from the USDA-NRCS [26] report. Production costs of

144 switchgrass were obtained from Turhollow and Epplin [27] showed in table 1, while cost of

145 grain-only wheat production was taken from the Oklahoma State University, enterprise budget

146 database [28]. The price of wheat was obtained from the Food and Agricultural Policy Research

147 Institute baseline model [29]. Environmental outcomes were valued based on previously

148 published literature.

149 2.1. EPIC model validation and simulation

150

Switchgrass was assumed to be seeded with a no-till drill at a planting rate of $5.6 \mathrm{~kg} \mathrm{ha}{ }^{-}$

151 , established, but not harvested, in year one. From year two onwards it was assumed to be

152 fertilized with $78 \mathrm{~kg}$ of nitrogen $\mathrm{ha}^{-1} \mathrm{y}^{-1}$. It was assumed that one condition of the land contract is

153 that the land owner would be responsible for the cost of any phosphorus and potassium fertilizer

154 and lime necessary for adequate $\mathrm{pH}$, and adequate soil levels of phosphorus and potassium prior

155 to switchgrass establishment [30]. The switchgrass plants are assumed to be cut at a height of

156 about $15 \mathrm{~cm}$. Plant material between the soil surface and $15 \mathrm{~cm}$ is assumed to be retained to

157 maintain healthy stands. The mowed switchgrass biomass was assumed to be harvested (baled)

158 once in October in each year. Production practices budgeted to estimate the cost of switchgrass

159 establishment, maintenance, and harvest were based on a no-till establishment system [27]. Table

1601 includes estimates of switchgrass production and harvest costs.

161 According to EPIC v. 0509 users guide "MUSLE, MUSS, and MUST usually give

162 similar results and are appropriate for estimating sediment yield from small watersheds up to

163 about $250 \mathrm{~km}^{2}$. The USLE is an erosion equation that is useful in studies like assessing the effect

164 of erosion on productivity. RUSLE is preferred for steep slopes > 20\%." [31]. The area of our 
165 study region $(65,382 \mathrm{ha})$ is 2.6 times the size of a small watershed of $25,000 \mathrm{ha}\left(250 \mathrm{~km}^{2}\right)$

166 suggested in the EPIC users guide, and the highest slope in our study region is 4\% (Table 5).

167 Therefore, instead of MUSLE (Modified-USLE) or RUSLE (Revised-USLE) which are used

168 either for small watersheds or for the slopes greater than $20 \%$ [31], we choose USLE equation

169 while establishing the EPIC simulation for the environmental outcomes.

170 The expected yields and the selected environmental outcomes for wheat and switchgrass

171 production were simulated using the EPIC model. For wheat, only the grain was removed. Wheat

172 residue was assumed to be returned to the soil surface. The EPIC crop yield estimates were

173 calibrated and validated prior to executing the scenarios. The switchgrass and wheat yields were

174 validated against results obtained from experimental field trial data $[32,33]$ shown in table 2 ,

175 while the EPIC simulated soil loss for both switchgrass and wheat production were validated

176 against the soil loss estimated using the USLE equation [22] shown in table 3. However, in the

177 absence of any field trail SOC accumulation information, calibration of SOC could not be

178 performed.

After the yields and the soil loss for both no-till wheat and switchgrass production are

180 calibrated and validated, the calibrated models were used to simulate wheat and switchgrass

181 yields and environmental outcomes based on 50 years of daily weather information. Each year's

182 data was considered as a state of nature. The EPIC switchgrass simulation was performed under

183 the assumption that crop land was converted from wheat to switchgrass and replanted every tenth

184 year. Ten different 50 year random weather scenarios were generated based on a unique random

185 number generator seed used in the EPIC control table. Each of these random weather scenarios

186 was used to simulate a 50-year yield distribution along with the selected environmental outcomes

187 for each county and each land class. The expected switchgrass and wheat yields and 
environmental outcomes were then based on the results of the ten 50 year simulations (using random weather) for each crop.

\section{$2.2 \quad$ Economic model}

Site-specific enterprise budgets based on the detailed field operations for both crops were prepared for each county for each of three land capability classes [27, 28]. The foregone profit from the best alternative use, wheat production, was considered as the opportunity cost of the land for each land class (I, II, and III) and for each county. However, in this study while estimating the farm-gate breakeven price of switchgrass land was valued at a rate in excess of the revenue lost from not producing wheat. This is based on the assumption that a landowner would require an incentive to convert cropland from an annual crop to the perennial switchgrass [34].

Therefore, land value is the opportunity costs of the land derived from the forgone wheat production plus the extrapolated USDA [35] cropland rental rate ${ }^{1}$. Since the switchgrass and wheat production costs were not inflated, a real rate of interest was used as the discount rate with the assumption that all prices will change as per the general inflation rate [36]. In the USA, the average real rate of interest over the last 15 years was $4 \%$ [37]. Therefore, a discount rate of $4 \%$ was used.

The net present value derived from wheat production in each county for each soil type from the profit maximizing landowners' perspective is estimated using the following equation:

$E\left(N P V P_{c, s}^{w}\right)=\sum_{i=1}^{n}\left(\frac{p_{i}^{w} E\left(Y_{i, c, s}^{w}\right)-V C_{i, c, s}^{w}}{(1+r)^{i}}\right)$

\footnotetext{
${ }^{1}$ USDA cropland rental rate is extrapolated using the following equation: $\omega_{i j}=\mu_{i j}\left(\sum_{j} X_{i j} x_{i} / \sum_{j} \mu_{i j} X_{i j}\right), \omega_{i j}$ is the rental cost of a hectare of land in county $i$ and land class $j ; \mu_{i j}$ is the potential wheat yield in county $i$ and land class $j$ as reported in the SSURGO data base, and; $X_{i j}$ is the available hectares of land in county $i$ and land class $j ; \chi_{i}$ is the USDA reported cropland rental rate for the county $i$
} 
207 where $\mathrm{E}\left(N P V P_{\mathrm{c}, s}^{w}\right)$ is the expected private profit maximizing landowners' net present value

208 derived from wheat production $w$ for county $c$ and land class type $s ; P^{w}{ }_{i}$ is the price of wheat $w$ in

209 year $i ; E\left(Y_{i, \mathrm{c}, s}^{w}\right)$ is the expected wheat yield $w$ for the $i^{\text {th }}$ year and for county $c$ and land class type

$210 s ; V C^{w}{ }_{i, \mathrm{c}, s}$ is the entire production cost including the establishment costs, fertilizer costs, and

211 harvesting costs of wheat production $w$ in $i^{\text {th }}$ year for county $c$ and land class type $s$; and $r$ is the

212 market discount rate. No value is included in the equation for wheat straw. Wheat produced in

213 the region does not consistently produce sufficient residue to collect for biomass feedstock. Over

214 years, plant breeders have bred and selected semi-dwarf hard red winter wheat varieties for grain

215 production and disease resistance rather than straw production.

216

The net present value derived from switchgrass production in each county for each soil is

217 estimated using the following equation:

218

$E\left(N P V P_{c, s}^{g}\right)=\sum_{i=1}^{n}\left(\frac{B E P_{c, s}^{g} E\left(Y_{i, c, s}^{g}\right)-E\left(Y_{i, c, s}^{g}\right) H C_{i, c, s}^{g}-V C_{i, c, s}^{g}-L C_{c, s}}{(1+r)^{i}}\right)$

219 where $\mathrm{E}\left(N P V P_{\mathrm{c}, s}^{g}\right)$ is the expected private profit maximizing land owners' net present value

220 derived from switchgrass production $g$ for county $c$ and land class type $s ; B E P_{c, s}^{g}$ is the private

221 profit maximizing land owners' farm-gate breakeven price of switchgrass $g$ for county $c$ and land

222 class type $s ; E\left(Y_{i, \mathrm{c}, s}^{g}\right)$ is the expected switchgrass yield $g$ for the $i^{\text {th }}$ year and for county $c$ and land

223 class type $s ; H C^{g}{ }_{i, c, s}$ is the harvesting costs of switchgrass production $g$ in $i^{\text {th }}$ year for county $c$

224 and land class type $s ; V C_{i, \mathrm{c}, s}^{g}$ is the fixed production cost including the establishment costs,

225 fertilizer costs and other costs of switchgrass production $g$ in $i^{\text {th }}$ year for county $c$ and land class

226 type $s ; L C_{c, s}$. is the extrapolated USDA [35] cropland rental rate for county $c$ and land class type

$227 s$,to represent additional payment made to incentivize the landowner/farmer to switch from wheat

228 to the perennial switchgrass. 
The landowner/farmer would be indifferent between producing either wheat or

230 switchgrass only when the net present value derived from producing wheat would be identical to

231 the net present value derived from producing switchgrass. Therefore, the farm-gate breakeven

232 price of switchgrass derived from private profit maximizing landowners' perspective is estimated

233 by equating equation 1 and equation 2, and solving for $B E P_{c, s}^{g}$.

\section{$234 \quad 2.3 \quad$ Environmental Analysis}

The environmental analysis portion of this study deals with determining the differences in

236 soil erosion, nitrogen and phosphorous runoff, and changes in SOC that would occur from

237 converting traditional wheat production land into switchgrass production. The EPIC model was

238 used to simulate 50-year site-specific distribution of environmental outcomes including nitrogen

239 loss, phosphorous loss, off-site soil erosion, and changes in SOC derived from switchgrass and

240 wheat production for each of the ten different random weather scenarios for each location. Site-

241 specific simulated expected environmental outcomes were then estimated for each of the selected

242 counties and land classes.

Each of the selected environmental variables (soil loss, fertilizer runoff, and SOC) would

244 impose environmental consequences on the surrounding watershed and the atmospheric carbon

245 cycle. The economic consequences of these environmental outcomes can be modeled either in

246 terms of damage cost or abatement cost. The optimal level of abatement occurs where the

247 marginal damage costs equal marginal treatment costs.

Several previous studies have estimated the costs associated with the abatement of

249 agricultural runoff including nitrogen and phosphorous, and the off-site damage costs of soil

250 erosion. Gerlach and DeSimone [38] estimated the abatement costs of nitrogen in Maryland to be

$25113 \$ \mathrm{~kg}^{-1}$. Zivojinovich [39] estimated nitrogen abatement costs of $55 \$ \mathrm{~kg}^{-1}$ using algal turf 
252 scrubber. Ribaudo et al. [40] estimated a US average nitrogen abatement cost using wetland 253 restoration of $6.37 \$ \mathrm{~kg}^{-1}$. Rabotyagov et al. [41] estimated that an abatement cost of $6.67 \$ \mathrm{~kg}^{-1}$ 254 would be required to reduce nitrogen loading by $30 \%$ through the reduction in the nitrogen 255 fertilizer application on fields in the upper Mississippi River basin. Non-point phosphorous abatement costs were estimated by Johansson and Randell [42],

257 Johansson et al. [43], Keplinger et al. [44], and Ancev et al. [45]. Ancev et al. [45] estimated 258 marginal phosphorous abatement costs equivalent with marginal damage costs from phosphorous 259 pollution for the Eucha-Spavinaw watershed in Oklahoma to range from $14.16 \$ \mathrm{~kg}^{-1}$ to $70.17 \$$ $260 \mathrm{~kg}^{-1}$. Estimates of off-site damage costs from soil erosion including the non-monetary 261 recreational values have also been produced in several previous studies [46-48].

262 In this study, the costs of abating nitrogen is assumed to be $6.37 \$ \mathrm{~kg}^{-1}$ based on the

263 Ribaudo et al. [40] estimated USA average nitrogen abatement costs; while phosphorus, and off264 site soil erosion damage are assumed to be $25.83 \$ \mathrm{~kg}^{-1}$, and $3.15 \$ \mathrm{Mg}^{-1}$, respectively based on 265 an estimate produced by Ancev et al. [45] for the Eucha-Spavinaw watershed which is located in 266 Oklahoma near the study area, and Ribaudo's [47] estimated off-site soil erosion damage costs 267 for the US southern plains (all these values are in 2012 US dollars [49]). According to 268 Bloomberg new energy finance [50], carbon credits have been auctioned for $12 \$ \mathrm{Mg}^{-1}$ to $15 \$$ $269 \mathrm{Mg}^{-1}$ of $\mathrm{CO}_{2}$ by the California Air Resources Board. Therefore, the value of sequestering SOC 270 was assumed to be $15 \$ \mathrm{Mg}^{-1} \mathrm{CO}_{2}$.

271 The net present value derived from wheat production in each county for each soil type 272 when considering the selected environmental variables is:

273 $E\left(N P V S_{c, s}^{w}\right)=\sum_{i=1}^{n}\left(\frac{p_{i}^{w} E\left(Y_{i, c, s}^{w}\right)-V C_{i, c, s}^{w}-\alpha N_{i, c, s}^{w}-\beta P_{i, c, s}^{w}-\lambda S L_{i, c, s}^{w}}{(1+r)^{i}}\right)$ 
274 where $\mathrm{E}\left(N P V S^{w}{ }_{\mathrm{c}, s}\right)$ is the expected net present value derived from wheat production $w$ for county

$275 c$ and land class type $s$; the additional terms $N_{i, c, s}^{w}$ and $P_{i, c, s}^{w}$ are the quantity of nitrogen and

276 phosphorous runoff in $\mathrm{kg} \mathrm{ha}^{-1}$ derived from wheat production for the $i^{\text {th }}$ year and for county $c$ and

277 land class type $s ; S L_{i, c, s}^{w}$ is the quantity of soil loss in $\mathrm{Mg} \mathrm{ha}^{-1}$ derived from wheat production for

278 the $i^{\text {th }}$ year and for county $c$ and land class type $s ; \alpha, \beta$ are the abatement costs of nitrogen and

279 phosphorous runoff respectively; and $\lambda$ is the damage costs associated with the soil loss.

280

The net present value derived from switchgrass production in each county for each soil

281 type when considering the selected environmental variables is:

282

$E\left(N P V S_{c, s}^{g}\right)=\sum_{i=1}^{n}\left(\frac{B E S_{c, s}^{g} E\left(Y_{i, c, s}^{g}\right)+\delta C_{i, c, s}^{g}-E\left(Y_{i, c, s}^{g}\right) H C_{i, c, s}^{g}-V C_{i, c, s}^{g}-L C_{c, s}-\alpha N_{i, c, s}^{g}-\beta P_{i, c, s}^{g}-\lambda S L_{i, c, s}^{g}}{(1+r)^{i}}\right)$

283 where $\mathrm{E}\left(\mathrm{NPVS}{ }_{c, s}^{g}\right)$ is the net present value derived from switchgrass production $g$ for county $c$

284 and land class type $s ; B E S_{c, s}^{g}$ is the farm-gate breakeven price of switchgrass $g$ for county $c$ and

285 land class type $s$ including selected environmental values; $C_{i, c, s}^{g}$ is the net change in the quantity

286 of SOC $\left(\mathrm{Mg} \mathrm{ha}^{-1}\right)$ derived from switching to switchgrass production $g$ from wheat production for

287 the $i^{\text {th }}$ year and for county $c$ and land class type $s ; N_{i, c, s}^{w}, P_{i, c, s}^{w}$ and $S L_{i, c, s}^{g}$ are the quantity of

288 nitrogen and phosphorous runoff in $\mathrm{kg} \mathrm{ha}^{-1}$ and the quantity of soil loss in $\mathrm{Mg} \mathrm{ha}^{-1}$ derived from

289 switchgrass production $g$ for the $i^{\text {th }}$ year and for county $c$ and land class type $s ; \delta$ is the carbon

290 credit $\left(\$ \mathrm{Mg}^{-1}\right)$ producers' received for sequestering carbon by producing switchgrass; and other

291 variables are as previously defined. Equating equation 3 and equation 4, and solving for $B E S_{c, s}^{g}$

292 the site-specific farm-gate breakeven price of switchgrass was estimated for the internal costs

293 plus selected external environmental consequences.

$294 \quad 2.4 \quad$ Sensitivity Analysis

295 Further, the sensitivity of the farm-gate breakeven price of switchgrass obtained under

296 both scenarios (with and without considering the consequences of the selected environmental 
297

298

299

300

301

302 production.

303

304

305

306

307

308

309

310

311

312

313

314

315

316

317

318

319

outcomes) was examined. We analyzed three different scenarios to determine the robustness of our finding. These are: (a) doubled the rate of interest: a key parameter in estimating the NPVs'; (b) doubled the price of wheat: crucial in determining the opportunity cost of the land for each land class (I, II, and III); and (c) doubled the land rental rate: played significant role in incentivizing the landowner/farmer to move land from wheat to the perennial switchgrass

\section{Results}

The EPIC model predicts that there will be a significant reduction in nitrogen loss, phosphorous loss, and soil loss if no-till wheat production is replaced by switchgrass production.

The site-specific reduction in estimated nitrogen loss ranges from $23.51 \mathrm{~kg}^{-1} \mathrm{ha}^{-1} \mathrm{y}^{-1}$ on land class I in Hughes County to $68.54 \mathrm{~kg}^{-1} \mathrm{ha}^{-1} \mathrm{y}^{-1}$ on land class III in Hughes County. The estimated reduction in soil loss ranges from $0.40 \mathrm{Mg}^{-1} \mathrm{ha}^{-1} \mathrm{y}^{-1}$ on land class II in Lincoln County to 2.71 $\mathrm{Mg}^{-1} \mathrm{ha}^{-1} \mathrm{y}^{-1}$ on land class III in Hughes County. The estimated reduction in phosphorous loss ranges from $0.02 \mathrm{~kg}^{-1} \mathrm{ha}^{-1} \mathrm{y}^{-1}$ on land class II in Latimer County to $1.89 \mathrm{~kg}^{-1} \mathrm{ha}^{-1} \mathrm{y}^{-1}$ on land class III in McIntosh County. These are the net changes estimated from replacing no-till wheat production with switchgrass production (Table 4). The potential environmental benefits from converting land from no-till grain only wheat to switchgrass is greater on land more prone to erosion (land class III in this study region).

The production of switchgrass can also sequester SOC. In an average year the sitespecific net increase in SOC derived from replacing no-till wheat with switchgrass ranges from $122.10 \mathrm{~kg} \mathrm{ha}^{-1}$ on land class III in Hughes County to $531.41 \mathrm{~kg} \mathrm{ha}^{-1}$ also in Hughes County on land class I (Table 4). However, the SOC accumulation is greater on land class I compared to land class II and III, due to increased plant biomass. In the absence of data required to calibrate 
320 the EPIC model to observed SOC changes in response to regional conditions, these results

321 completely rely on default EPIC values for simulating SOC values which are not consistent with

322 the findings reported by Follett et al. [51]. They argue that essentially the SOC accumulation for

323 switchgrass production remains in the same range regardless of the difference in the biomass

324 yield. Another study done by Mondzozo et al. [52] showed that in the presence of carbon price

325 switchgrass was favored over crop residue as an alternative feedstocks. Irrespective of the

326 relationship between the biomass yield and SOC accumulation both study showed that the SOC

327 accumulation has significantly increased with switchgrass production. However, whether SOC

328 accumulation remain the same across different biomass yield or not does not change the finding

329 of our study.

330 The average reductions in soil, nitrogen, and phosphorous losses estimated from

331 switchgrass production on land class I are lower as compared to the estimated reductions for land

332 classes II and III (Figure 2). The greatest environmental benefits occurred for land class III (with

333 a slope gradient of 4\%) in Hughes, McIntosh, and Pittsburg counties, which resulted from

334 replacing no-till wheat production with switchgrass production (Table 4). On the other hand,

335 switchgrass produced on land class I sequesters more carbon than that produced on land class II

336 and class III (Figure 2). Therefore, converting land class III from no-till wheat to switchgrass

337 production is associated with greater reduction in runoff and thus more beneficial to society

338 compared to converting class I, and class II land.

339 The site-specific farm-gate breakeven price of switchgrass derived from the profit

340 maximizing private landowner's (internal returns and cost) perspective ranges from $37 \$ \mathrm{Mg}^{-1}$

341 (Pottawatomie County land class I) to $66 \$ \mathrm{Mg}^{-1}$ (Johnston County land class I) (Table 5).

342 Switchgrass produced on land class III of each county has a higher farm-gate breakeven price 
343 compare to the switchgrass produced on land class I and land class II, due to lower yields.

344 However, when the selected environmental consequences are valued and considered (on-farm

345 plus environmental benefits) the breakeven price declines and ranges from $11 \$ \mathrm{Mg}^{-1}$ (Hughes

346 County land class III) to $39 \$ \mathrm{Mg}^{-1}$ (Johnston County land class I). The average farm-gate

347 breakeven price of switchgrass derived from the private landowners' perspective increases as the

348 average yields decrease from good quality soil to lower quality soil. However, when selected

349 environmental outcomes are valued then the average farm-gate switchgrass breakeven price

350 decreases from good quality soil to lower quality soil. The selected environmental benefits

351 derived from converting no-till wheat to switchgrass production on lower quality soil offsets the

352 revenue loss due to lower yields on the lower quality soil.

353 Replacing no-till wheat production in Hughes County on land class III resulted in the 354 greatest reduction in runoff and at the same time has the lowest SOC accumulation (Table 5).

355 However, the benefits derived from reducing runoff exceeded the benefits derived from lower 356 accumulation of SOC in Hughes County land class III compared to land class I and land class II 357 of the same county, resulting in the lowest farm-gate breakeven price of switchgrass in Hughes 358 County on land class III. Land class III of Hughes County, McIntosh County land class III and 359 Pittsburg County land class III with a slope gradient of $4 \%$ has the highest potential runoff 360 reduction from replacing no-till wheat with switchgrass, and also has the lowest farm-gate 361 breakeven price of switchgrass $11 \$ \mathrm{Mg}^{-1}, 13 \$ \mathrm{Mg}^{-1}$, and $13 \$ \mathrm{Mg}^{-1}$, respectively (Table 5) if the 362 external costs are considered.

The difference between the farm-gate breakeven prices derived from the internal returns 364 and cost perspective and the on-farm plus selected environmental consequences perspective 365 (Table 5) range from $13 \$ \mathrm{Mg}^{-1} \mathrm{y}^{-1}$ on land class I in Latimer County to $46 \$ \mathrm{Mg}^{-1} \mathrm{y}^{-1}$ on land 
class III in Pittsburg County. As expected these differences are highest for land class III in Hughes, McIntosh, and Pittsburg counties. When multiplied by the average switchgrass yield of $9 \mathrm{Mg} \mathrm{ha}^{-1} \mathrm{y}^{-1}$, the environmental benefits derived from replacing no-till wheat with switchgrass on these highly erodible lands for land class III in Hughes, McIntosh, and Pittsburg counties would be on average $408 \$ \mathrm{ha}^{-1} \mathrm{y}^{-1}$.

The potential environmental benefits from converting land from no-till wheat to switchgrass production to produce feedstock for one potential 700,000 Mg $\mathrm{y}^{-1}$ biorefinery can be estimated by multiplying these differences by the average yields per hectare and by the hectares of land converted for each land class and in each county (Table 5). The environmental benefit ranges from 5,652 \$ for 14 ha of McIntosh County land class I cropland to $3.47 \$$ x $10^{6}$ for 6,368 ha of land class III cropland in Hughes County. In an average year, around $26 \$$ x $10^{6}$ of environmental benefits could accrue to society from converting no-till wheat to switchgrass on 65,382 ha to produce feedstock for a single $700,000 \mathrm{Mg} \mathrm{y}^{-1}$ biorefinery. These benefits follow from the assumptions that (a) the change in wheat production will be sufficiently small to not affect the wheat price; and (b) that the reduction of wheat produced in these counties will not provide an incentive for farmers elsewhere to increase land area seeded to wheat. On average, the highest annual environmental benefits were predicted for land class III (Figure 3). Therefore, converting the most erodible land from wheat to the production of switchgrass has the greatest potential environmental benefits. Therefore, any public policies designed to incentivize feedstock production might best serve the interest of society by including land quality considerations. Results obtained from the sensitivity analysis of the site-specific breakeven price of switchgrass are shown in table 6 . It is found that none of the results significantly change when (a) the discount rate is increased from $4 \%$ to $8 \%$; (b) when the expected wheat price is doubled; 
389 and (c) when the land rental values are doubled. The farm-gate breakeven price of switchgrass

390 derived from only internal costs is greater than the farm-gate breakeven price of switchgrass

391 derived from on-farm plus environmental benefits.

\section{$392 \quad 4 . \quad$ Discussion}

This study found that switchgrass production has the potential to reduce nitrogen and

394 phosphorous runoff, reduce soil loss, and increase sequestration of SOC, resulting in

395 environmental benefits as compared to no-till wheat production. The economic differences in the

396 environmental benefits between switchgrass production and no-till wheat production were

397 determined by placing specific monetary values on the environmental benefits. Valuing selected

398 environmental benefits derived from switchgrass production reduces the site-specific farm-gate

399 breakeven price of switchgrass. The difference between the farm-gate breakeven prices of

400 switchgrass derived from considering only the internal returns and cost and from considering on-

401 farm plus selected environmental consequences was estimated to be greatest at $46 \$ \mathrm{Mg}^{-1} \mathrm{y}^{-1}$ on

402 land class III in Pittsburg County and lowest at $13 \$ \mathrm{Mg}^{-1} \mathrm{y}^{-1}$ on land class I in Latimer County.

403 Switchgrass production results in relatively greater environmental benefits when it is used to

404 replace wheat grown on the most highly erodible land (land class III). Consideration of

405 differences in environmental consequences and potential benefits to society would be appropriate

406 if public policies are used to incentivize switchgrass production.

407 Sites with a slope gradient of $4 \%$ within the study area (Hughes County land class III,

408 McIntosh County land class III and Pittsburg County land class III) have an average annual

409 estimated environmental benefit of $408 \$ \mathrm{ha}^{-1}$ for reducing runoff by converting from no-till

410 wheat to switchgrass. 
In USA, the government established the Conservation Reserve Program (CRP) in 1985.

412 Under the CRP program, highly erodible land was removed from agricultural production and

413 planted to trees or perennial grasses [53]. Land included in the CRP is required to have an

414 erodibility index equal to or greater than eight [54]. According to the estimated erodibility index,

415 Hughes County land class III, McIntosh County land class III, and Pittsburg County land class

416 III would qualify for inclusion in the CRP. Results show that when environmental benefits are

417 considered the farm-gate breakeven price of switchgrass is lowest in those counties.

As noted, the estimated environmental benefits are contingent on the assumptions that

419 conversion of cropland to switchgrass would not affect the wheat price, and that the reduction of

420 wheat produced in these counties would not provide an incentive for farmers elsewhere to

421 convert idle land or pasture land to wheat. For a single biorefinery, these assumptions are

422 reasonable. However, if several million hectares were converted from cropland to switchgrass,

423 crop prices could be expected to increase, providing an incentive to bring land elsewhere into

424 crop production. As a result of the bulky nature of biomass, the production of dedicated biomass

425 crops and the conversion of biomass to biobased products is likely to be locally focused. The

426 environmental consequences of converting cropland to the production of dedicated energy crops

427 will depend on local conditions. Thus, care should be made to not extrapolate the findings of this

428 study to another region that has different soil and climate conditions and that produces other

429 crops that would be displaced. However, the methods used in this study could be applied to other

430 locations around the world. These findings could contribute to a more comprehensive life cycle

431 analysis of consequences at a local, single biorefinery, level.

\section{Acknowledgements}


433 The authors would like to thank the editor Dr. C.P. Mitchell and the three anonymous reviewers 434 for their thoughtful comments and suggestions that help us to improve this research paper. We 435 would also like to thank Dr. Philip W. Gassman for his helpful comments and suggestions. 436 Funding for this project was provided by the USDA-NIFA, USDA-DOE Biomass Research and 437 Development Initiative, Grant No. 2009-10006-06070, by Hatch grant number H-2824, and by 438 the Oklahoma Agricultural Experiment Station. Support does not constitute an endorsement of 439 the findings expressed. 


\section{References}

[1] Oklahoma State University, Department of Plant and Soil Science. Switchgrass: Environmental Impacts. 2014. http://switchgrass.okstate.edu/environmentalimpacts/environmental-impacts [accessed 13.04.2014].

[2] McLaughlin SB. New switchgrass biofuels research program for the Southeast. Proceedings of the Annual Automobile Technology Development Contractors' Coordination Meeting, Michigan, USA, Nov. 2-5, 1992. p. 111-115.

[3] Monti A, Fazio S, Lychnaras V, Soldatos P, Ventri G. A full economic analysis of switchgrass under different scenarios in Italy estimated by BEE model. Biomass and Bioenerg 2007;(31):177-185.

[4] Smeets EMW, Lewandowski IM, Faaij APC. The economical and environmental performance of miscanthus and switchgrass production and supply chains in a European setting. Renew and Sustainable Energy Reviews 2009;(13):1230-1245.

[5] Samson RA, Omielan JA. Switchgrass: A potential biomass energy crop for ethanol production. Proceedings of the Thirteenth North American Prairie Conference: spirit of the land, our prairie legacy, Ontario, CA: Aug. 6-9, 1992. p. 253-1258.

[6] van Dam J, Faaij APC, Petruzzi H, Turkenburg WC. Large-scale bioenergy production from soybeans and switchgrass in Argentina part B: Environmental and socio-economic impacts on a regional level. Renew and Sustainable Energy Reviews 2009;(13):1679-1709.

[7] Ichizen N, Takahashi H, Nishio T, Liu G, Li D, Huang J. Impacts of switchgrass (Panicum virgatum L.) planting on soil erosion in the hills of the Loess Plateau in China. Weed Biology Management 2005;(5):31-34. 
[8] Ma Y, An Y, Shui J, Sun Z. Adaptability evaluation of switchgrass (Panicum virgatum L.) cultivars on the Loess Plateau of China. Plant Science 2011;(181):638-643.

[9] US Environmental Protection Agency. Renewable Fuel Standard Program (RFS2) regulatory impact analysis. 2012. http://nepis.epa.gov/Adobe/PDF/P1006DXP.PDF [accessed 03.03.2012].

[10] Mooney DF, Roberts RK, English BC, Tyler DD, Larson JA. Yield and breakeven price of ‘Alamo’ switchgrass for biofuels in Tennessee. Agron J 2009;(101):1234-1242.

[11] Khanna M, Dhungana B, Brown JC. Costs of producing miscanthus and switchgrass for bioenergy in Illinois. Biomass and Bioenerg 2008;(32):482-93.

[12] Epplin FM, Clark CD, Roberts RK, Hwang S. Challenges to the development of a dedicated energy crop. Amer J Agr Econ 2007;(89):1296-1302.

[13] McLaughlin SB, Kszos LA. Development of switchgrass (panicum virgatum) as a bioenergy feedstock in the United States. Biomass and Bioenerg 2005;(28):515-535.

[14] Nelson RG, Ascough II JC, Langemeier MR. Environmental and Economic Analysis of Switchgrass Production for Water Quality Improvement in Northeast Kansas. J Environ Manage 2006;(79):336-347.

[15] Arnold JG, Moriasi DN, Gassman PW, Abbaspour KC, White MJ, Srinivasan R, Santhi C, Harmel RD, Griensven van A, Van Liew NW, Kannan N, Jha MK. SWAT: Model use, calibration, and validation. T ASABE. 2012;55(4):1491-1508.

[16] Gassman PW, Reyes MR, Green CH, and Arnold JG. The Soil and Water Assessment Tool: historical development, applications, and future research directions. T ASABE 2007;50(4): $1211-1250$. 
[17] Williams JR, Arnold JG, Kiniry JR, Gassman PW, Green CH. History of model development at Temple, Texas. Hydrolog Sci J 2008;53(5): 948-960. Doi: 10.1623/hysj.53.5.948.

[18] Graham RL, Downing M, Walsh ME. A framework to assess regional environmental impacts of dedicated energy crop production. Environ Manage 1996;(20):475-485.

[19] Williams JR, Jones CA, Dyke PT. A modeling approach to determining the relationship between erosion and soil productivity. T ASAE 1984;(27):129-144.

[20] Williams JR. The erosion productivity impact calculator (EPIC) model: a case history. Phil Trans R Soc Lond. 1990;(329): 421-428.

[21] King JE, Hannifan JM, Nelson RG. An assessment of the feasibility of electric power derived from biomass and waste feedstock. Report No. KRD-9513. Kansas Electric Utility Research Program and Kansas Corporation Commission, Topeka, KS. 1998. p. 280.

[22] Debnath D. Three Essays: Reservoir Management; Switchgrass Land Leasing; and its Environmental Impact. Ph.D. Dissertation, Department of Agricultural Economics, Oklahoma State University, Stillwater, OK. 2012.

[23] National Oceanographic Atmospheric Administration, National Climatic Data Center, National Climatic Data Center. Daily weather data for Oklahoma 1961-1994. http://gis.ncdc.noaa.gov/map/cdo/ [accessed 02.03.2012].

[24] Mesonet Oklahoma. Oklahoma Climatological Survey: Daily weather data. 2011. http://www.mesonet.org/index.php/weather/category/past_data_files [accessed 02.02.2012].

[25] US Department of Agriculture. Soil Service Geographic (SSURGO) Database for Oklahoma, 2011. http://soils.usda.gov/survey/geography/ssurgo/ [accessed 08.15.2011]. 
507

508

509

510

511

512

513

514

515

516

517

518

519

520

521

522

523

524

525

526

527

528

529

[26] US Department of Agriculture. NRCS Part 630 Hydrology National Engineering Handbook. Chapter 7. Hydrologic Soil Group, 2007. http://directives.sc.egov.usda.gov/OpenNonWebContent.aspx?content=17757.wba [accessed 10.24.2012].

[27] Turhollow AF, Epplin FM. Estimating region specific costs to produce and deliver switchgrass. Chapter 8 pp. 187-204 in Switchgrass: A valuable biomass crop for energy. ed. Andrea Monti, New York: Springer Publishing Co. 2012.

[28] Oklahoma State University. Agricultural economics agricultural budget software. Dryland wheat enterprise-grain only. Stillwater, OK. 2012.

[29] Food and Agricultural Policy Research Institute (FAPRI) Staff. 2010 U.S. and world agricultural outlook. Ames, IA: FAPRI at Iowa State University; 2010. P. 435, FAPRI Staff Report 07-fs 1 .

[30] Haque M, Epplin FM, Taliaferro CM. Nitrogen and harvest frequency effect on yield and cost for four perennial grasses. Agron J 2009;(101):1463-1469.

[31] Williams JR, Wang E, Meinardus A, Siemers M, Atwood JD. EPIC Users guide v. 0509. Temple, TX. 2006. http://epicapex.tamu.edu/files/2013/02/epic0509usermanualupdated.pdf [accessed 16.10.2011]

[32] Fuentes RG, Taliaferro CM. Biomass yields stability of switchgrass cultivars. Trends in new crops and new uses. J. Janick and A. Whipkey, eds. Alexandria, VA: ASHS Press. 2002. p. 276-82.

[33] Oklahoma State University. OSU small grains variety performance tests. Department of Plant and Soil Science, Stillwater, OK. 2012. http://wheat.okstate.edu/variety-testing/grainyield [accessed 03.02.2012] 
[34] Fewell J, Bergtold J, Williams J. Farmer's willingness to grow switchgrass as a cellulosic bioenergy crop: A stated choice approach." Paper presented at the joint annual meeting of the Canadian Agricultural Economics Society and Western Agricultural Economics Association, Banff, Alberta, Canada, June 29-July 1, 2011.

[35] US Department of Agriculture. National Agricultural Statistics Service (NASS) land values and cash rents, 2011. http://quickstats.nass.usda.gov/results/63D3252C-0498-3E63-99DD20935377B67D [accessed 02.14. 2012].

[36] Campbell HF, Brown RPC. Benefit-cost analysis financial and economic appraisal using spreadsheet. Melbourne, Australia: Cambridge University Press, 2009.

[37] World Bank. Real Rate of Interest (\%). International Monetary Fund, International Financial Statistics and data files using World Bank data on the GDP deflator. http://data.worldbank.org/indicator/FR.INR.RINR [accessed 10.04.2012].

[38] Gerlach SB, DeSimone C. Refinement of nitrogen removal from municipal wastewater treatment plants. Maryland Department of the Environment. 2005.

[39] Zivojnovich MJ. Algae based water treatment systems cost-effective nutrient population control and for point and nonpoint source applications. HydroMentia, Inc. Ocala, Florida, 2010. http://www.alachuacounty.us/Depts/EPD/WaterResources/SantaFeRiverSprings/ 110216_Algae\%20Turf\%20Scrubbers.pdf [accessed 03.05.2012].

[40] Ribaudo M, Delgado J, Hansen LR, Livingston M, Mosheim R, Williamson . Nitrogen in agricultural systems: Implication for conservation policy. RR -127. USDA, Economic Research Service, September 2011. 
551 [41] Rabotyagov S, Campbell T, Jha M, Gassman PW, Arnold J, Kurkalova L, Secchi S, Feng

552 H, Kling CL. Least-cost control of agricultural nutrient contributions to the gulf of Mexico hypoxic zone. Ecol Appl 2010;(20):1542-1555.

554 [41] Johansson RC, Randall J. Watershed abatement costs for agricultural phosphorous. Water $555 \quad$ Resour Res 2003;(4):3.1-3.8.

556 [43] Johansson RC, Gowda PH, Mulla DJ, Dalzell BJ. Metamodelling phosphorous best 557 management practices for policy use: a frontier approach. Agri Econ 2004;(30):63-74.

[44] Keplinger KO, Houser JB, Tanter AM, Hauck LM, Beran L. Cost and affordability of phosphorous removal at small wastewater treatment plants. Small Flow Quart 2005;(5):36-

[45] Ancev T, Stoecker AL, Storm DE, White MJ. The economics of efficient phosphorous abatement in a watershed.” J Agr and Resource Econ 2006;(31):529-548.

563 [46] Pimentel D, Harvey C, Resosudarmo P, Sinclair K, Kurz D, McNair M, Crist S, Shpritz L, 564 Fitton L, Saffouri R. and Blair R. Environmental and economic costs of soil erosion and conservation benefits." Science, New Series 1995;(267):1117-1123.

[47] Ribaudo M. Reducing soil erosion: offsite benefits. USDA, Economic Research Service. Agricultural Economic Report No. 561. 1986.

[48] Hauszar P, Piper S. Estimating the off-site costs of wind erosion in New Mexico. J Soil Water Conserv 1986;(41):414-416.

570 [49] U.S. Bureau of Labor Statistics. CPI inflation calculator, 2012. http://www.bls.gov/data/inflation_calculator.htm [accessed 09.12.2012]. 
572 [50] Lynn D. California carbon allowances sold out at \$10.09 in auction. 2012.

573 http://www.bloomberg.com/news/2012-11-19/california-carbon-allowances-sold- for-10-

574 09-in-first-auction.html [accessed 11.02.2012].

575 [51] Follett RF, Vogel KP, Varvel GE, Mitchell RB, Kimble J. Soil carbon sequestration by

576 switchgrass and no-till maize grown for bioenergy. Bioenerg Res 2012;(5):866-875.

577 [52] Mondzozo AE, Swinton SM, Izaurralde RC, Manowitz DH, Zhang X. Maintaining

578 environmental quality while expanding biomass production: Sub-regional U.S. policy

579 simulations. Energy Pol 2013;(57):518-531.

580 [53] Mapemba LD, Epplin FM, Taliaferro CM, Huhnke RL. Biorefinery feedstock production 581 on conservation reserve program land. Rev Agr Econ 2007;(29):227-246.

582 [54] US Department of Agriculture, Farm Service Agency Fact Sheet. 2013.

583 http://www.fsa.usda.gov/Internet/FSA_File/crpfactsheet0213.pdf [accessed 03.02.2012]. 
1 Table 1. Estimated annual production and harvesting costs of switchgrass.

\begin{tabular}{llccc}
\hline Item & Unit & Quantity & Price unit & Costs \\
\hline & & & $\$$ & $\$$ ha $^{-1}$ \\
Establishment costs & ha & 1.00 & & 394.45 \\
Land rental & ha & 1.00 & variable & variable \\
Establishment costs, amortized for 10 & & & & \\
years at 6.5\% & $\$$ & & 0.065 & variable \\
Nitrogen & $\mathrm{kg}$ & 78.00 & 1.23 & 95.94 \\
Annual Maintenance costs & $\$$ & 1.00 & & 9.63 \\
Mowing & ha & 1.00 & & 30.97 \\
Raking & ha & 1.00 & & 18.89 \\
Baling, 681 kg dry biomass rectangular & & & & \\
bale & $\mathrm{kg}$ & variable & 28.89 & variable \\
Total costs & $\$$ & & & variable \\
\hline
\end{tabular}

2 
3 Table 2. Comparison between measured and simulated no-till wheat and switchgrass yields

\begin{tabular}{lcccc}
\hline & \multicolumn{2}{c}{ Wheat } & \multicolumn{2}{c}{ Switchgrass } \\
\cline { 2 - 5 } & $\begin{array}{c}\text { Measured } \\
\text { yields }\end{array}$ & $\begin{array}{c}\text { Simulated } \\
\text { yields }\end{array}$ & $\begin{array}{c}\text { Measured } \\
\text { yields }\end{array}$ & $\begin{array}{c}\text { Simulated } \\
\text { yields }\end{array}$ \\
\hline Mean $\left(\mathrm{Mg} \mathrm{ha}^{-1}\right)$ & 2.70 & 2.65 & 14.68 & 14.41 \\
St. Dev. & 0.96 & 0.70 & 4.29 & 4.16 \\
Maximum $\left(\mathrm{Mg} \mathrm{ha}^{-1}\right)$ & 4.71 & 4.18 & 23.10 & 21.81 \\
Minimum $\left(\mathrm{Mg} \mathrm{ha}^{-1}\right)$ & 1.35 & 1.59 & 7.28 & 7.57 \\
\hline
\end{tabular}

4 
5 Table 3. Comparison between estimated and simulated soil loss derived from no-till wheat and 6 switchgrass production.

\begin{tabular}{lcccc}
\hline & \multicolumn{2}{c}{ Wheat } & \multicolumn{2}{c}{ Switchgrass } \\
\cline { 2 - 5 } & $\begin{array}{c}\text { USLE* } \\
\text { estimated soil } \\
\text { loss }\end{array}$ & $\begin{array}{c}\text { EPIC } \\
\text { simulated } \\
\text { soil loss }\end{array}$ & $\begin{array}{c}\text { USLE* } \\
\text { estimated } \\
\text { soil loss }\end{array}$ & $\begin{array}{c}\text { EPIC simulated } \\
\text { soil loss }\end{array}$ \\
\hline Mean $\left(\mathrm{Mg} \mathrm{ha}^{-1}\right)$ & 1.99 & 1.77 & 0.20 & 0.14 \\
St. Dev. & 1.62 & 1.23 & 0.16 & 0.10 \\
Maximum $\left(\mathrm{Mg} \mathrm{ha}^{-1}\right)$ & 7.46 & 5.81 & 0.75 & 0.51 \\
Minimum $\left(\mathrm{Mg} \mathrm{ha}^{-1}\right)$ & 0.42 & 0.40 & 0.04 & 0.02 \\
\hline
\end{tabular}


9 Table 4. Site-specific soil loss, nitrogen loss, phosphorous loss reduction and accumulation of 10 soil organic carbon (SOC) derived from replacing no-till wheat production with switchgrass 11 production.

\begin{tabular}{|c|c|c|c|c|c|}
\hline $\begin{array}{l}\text { County land class } \\
\text { (LC) }\end{array}$ & $\begin{array}{l}\text { Slope } \\
(\%)\end{array}$ & $\begin{array}{l}\text { Soil loss } \\
\text { reduction } \\
\left(\mathrm{Mg} \mathrm{ha}^{-1} \mathrm{y}^{-1}\right)\end{array}$ & $\begin{array}{l}\text { Nitrogen loss } \\
\text { reduction } \\
\left(\mathrm{kg} \mathrm{ha}^{-1} \mathrm{y}^{-1}\right)\end{array}$ & $\begin{array}{c}\text { Phosphorous } \\
\text { loss } \\
\text { reduction } \\
\left(\mathrm{kg} \mathrm{ha}^{-1} \mathrm{y}^{-1}\right)\end{array}$ & $\begin{array}{l}\text { Changes in } \\
\text { SOC } \\
\left(\mathrm{kg} \mathrm{ha}^{-1} \mathrm{y}^{-1}\right)\end{array}$ \\
\hline Creek LC-I & 0.5 & 1.4 & 43.6 & 0.8 & 158.2 \\
\hline Haskell LC-I & 1.0 & 1.3 & 46.4 & 0.9 & 390.9 \\
\hline Hughes LC-I & 1.0 & 0.8 & 23.5 & 1.3 & 531.4 \\
\hline Johnston LC-I & 0.5 & 1.3 & 38.3 & 1.0 & 367.3 \\
\hline Lincoln LC-I & 0.5 & 0.8 & 33.7 & 0.7 & 231.7 \\
\hline McIntosh LC-I & 0.5 & 1.4 & 41.0 & 0.4 & 524.8 \\
\hline Okfuskee LC-I & 0.5 & 1.2 & 37.8 & 0.7 & 156.0 \\
\hline Oklahoma LC-I & 0.5 & 0.4 & 33.6 & 0.4 & 412.3 \\
\hline Okmulgee LC-I & 1.0 & 1.2 & 31.4 & 1.2 & 467.8 \\
\hline Pittsburg LC-I & 1.0 & 1.2 & 34.0 & 0.4 & 419.4 \\
\hline Pottawatomie LC-I & 0.5 & 1.1 & 33.4 & 0.9 & 395.1 \\
\hline Seminole LC-I & 0.5 & 2.0 & 41.0 & 1.3 & 241.2 \\
\hline Wagoner LC-I & 1.0 & 0.8 & 29.1 & 0.7 & 157.8 \\
\hline Coal LC-II & 2.0 & 2.0 & 39.8 & 0.9 & 302.4 \\
\hline Creek LC-II & 2.0 & 1.2 & 43.6 & 1.0 & 151.9 \\
\hline Hughes LC-II & 2.0 & 1.0 & 36.0 & 1.3 & 261.0 \\
\hline Latimer LC-II & 1.0 & 0.5 & 25.7 & 0.0 & 294.5 \\
\hline Lincoln LC-II & 0.5 & 0.4 & 25.1 & 0.6 & 336.6 \\
\hline McIntosh LC-II & 2.0 & 3.0 & 59.5 & 1.4 & 404.8 \\
\hline Okfuskee LC-II & 0.5 & 0.6 & 25.9 & 0.1 & 319.9 \\
\hline Oklahoma LC-II & 0.5 & 0.9 & 44.4 & 0.7 & 309.6 \\
\hline Okmulgee LC-II & 2.0 & 1.7 & 52.4 & 1.2 & 326.4 \\
\hline Pittsburg LC-II & 2.0 & 2.3 & 47.7 & 0.7 & 209.0 \\
\hline Seminole LC-II & 0.5 & 0.9 & 41.0 & 1.3 & 241.2 \\
\hline Creek LC-III & 2.5 & 3.0 & 52.2 & 1.4 & 210.8 \\
\hline Hughes LC-III & 4.0 & 5.5 & 68.5 & 1.3 & 122.1 \\
\hline McIntosh LC-III & 4.0 & 3.4 & 66.0 & 1.9 & 290.2 \\
\hline Muskogee LC-III & 2.0 & 3.3 & 29.1 & 0.7 & 194.2 \\
\hline Okfuskee LC-III & 0.5 & 0.5 & 25.9 & 0.1 & 279.9 \\
\hline Okmulgee LC-III & 1.0 & 1.5 & 31.1 & 0.5 & 432.9 \\
\hline Pittsburg LC-III & 4.0 & 3.7 & 63.2 & 1.5 & 154.1 \\
\hline Seminole LC-III & 2.0 & 1.9 & 55.2 & 1.5 & 135.9 \\
\hline Wagoner LC-III & 1.0 & 1.3 & 56.2 & 1.1 & 137.8 \\
\hline
\end{tabular}


Table 5. Site-specific farm-gate breakeven price of switchgrass with and without valuing the

14 selected environmental consequences, the differences between them, and hectares of land leased

15 of each land class for each county, and the corresponding environmental benefits.

\begin{tabular}{|c|c|c|c|c|c|c|}
\hline $\begin{array}{l}\text { County land class } \\
\text { (LC) }\end{array}$ & $\begin{array}{c}\text { Slope } \\
(\%)\end{array}$ & $\begin{array}{c}\text { Internal } \\
\text { breakeven } \\
\text { price }\left(\mathrm{Mg}^{-1}\right)\end{array}$ & $\begin{array}{c}\text { Internal } \\
\& \\
\text { external } \\
\text { breakeven } \\
\text { price } \\
\left(\mathrm{Mg}^{-1}\right)\end{array}$ & $\begin{array}{l}\text { Difference* } \\
\left(\mathrm{Mg}^{-1}\right)\end{array}$ & $\begin{array}{c}\text { Land } \\
\text { (ha) }\end{array}$ & $\begin{array}{c}\text { Environmental } \\
\text { benefits }\end{array}$ \\
\hline Creek LC-I & 0.5 & $\$ 48$ & $\$ 25$ & $\$ 23$ & 1,337 & $\$ 470,180$ \\
\hline Haskell LC-I & 1.0 & $\$ 53$ & $\$ 28$ & $\$ 24$ & 65 & $\$ 28,472$ \\
\hline Hughes LC-I & 1.0 & $\$ 49$ & $\$ 30$ & $\$ 19$ & 329 & $\$ 99,123$ \\
\hline Johnston LC-I & 0.5 & $\$ 66$ & $\$ 39$ & $\$ 27$ & 107 & $\$ 51,403$ \\
\hline Lincoln LC-I & 0.5 & $\$ 53$ & $\$ 36$ & $\$ 18$ & 251 & $\$ 75,644$ \\
\hline McIntosh LC-I & 0.5 & $\$ 51$ & $\$ 24$ & $\$ 26$ & 14 & $\$ 5,652$ \\
\hline Okfuskee LC-I & 0.5 & $\$ 50$ & $\$ 32$ & $\$ 18$ & 774 & $\$ 252,815$ \\
\hline Oklahoma LC-I & 0.5 & $\$ 54$ & $\$ 36$ & $\$ 19$ & 590 & $\$ 200,654$ \\
\hline Okmulgee LC-I & 1.0 & $\$ 49$ & $\$ 27$ & $\$ 22$ & 544 & $\$ 192,701$ \\
\hline Pittsburg LC-I & 1.0 & $\$ 53$ & $\$ 33$ & $\$ 20$ & 142 & $\$ 49,768$ \\
\hline Pottawatomie LC-I & 0.5 & $\$ 37$ & $\$ 20$ & $\$ 17$ & 669 & $\$ 211,861$ \\
\hline Seminole LC-I & 0.5 & $\$ 54$ & $\$ 32$ & $\$ 22$ & 120 & $\$ 44,981$ \\
\hline Wagoner LC-I & 1.0 & $\$ 52$ & $\$ 34$ & $\$ 18$ & 773 & $\$ 252,212$ \\
\hline Coal LC-II & 2.0 & $\$ 51$ & $\$ 34$ & $\$ 16$ & 999 & $\$ 275,298$ \\
\hline Creek LC-II & 2.0 & $\$ 51$ & $\$ 16$ & $\$ 34$ & 3,647 & $\$ 1,422,695$ \\
\hline Hughes LC-II & 2.0 & $\$ 50$ & $\$ 28$ & $\$ 23$ & 2,645 & $\$ 934,153$ \\
\hline Latimer LC-II & 1.0 & $\$ 50$ & $\$ 37$ & $\$ 13$ & 740 & $\$ 163,834$ \\
\hline Lincoln LC-II & 0.5 & $\$ 55$ & $\$ 37$ & $\$ 18$ & 2,895 & $\$ 815,349$ \\
\hline McIntosh LC-II & 2.0 & $\$ 56$ & $\$ 18$ & $\$ 38$ & 1,413 & $\$ 743,870$ \\
\hline Okfuskee LC-II & 0.5 & $\$ 52$ & $\$ 38$ & $\$ 15$ & 1,057 & $\$ 253,309$ \\
\hline Oklahoma LC-II & 0.5 & $\$ 56$ & $\$ 34$ & $\$ 22$ & 2,882 & $\$ 1,070,551$ \\
\hline Okmulgee LC-II & 2.0 & $\$ 52$ & $\$ 19$ & $\$ 33$ & 3,003 & $\$ 1,467,664$ \\
\hline Pittsburg LC-II & 2.0 & $\$ 55$ & $\$ 32$ & $\$ 24$ & 2,774 & $\$ 1,065,487$ \\
\hline Seminole LC-II & 0.5 & $\$ 54$ & $\$ 32$ & $\$ 22$ & 1,329 & $\$ 498,166$ \\
\hline Creek LC-III & 2.5 & $\$ 56$ & $\$ 12$ & $\$ 44$ & 3,842 & $\$ 1,757,661$ \\
\hline Hughes LC-III & 4.0 & $\$ 56$ & $\$ 11$ & $\$ 45$ & 6,348 & $\$ 3,472,148$ \\
\hline McIntosh LC-III & 4.0 & $\$ 58$ & $\$ 13$ & $\$ 45$ & 552 & $\$ 290,040$ \\
\hline Muskogee LC-III & 2.0 & $\$ 54$ & $\$ 37$ & $\$ 17$ & 4,623 & $\$ 1,181,251$ \\
\hline Okfuskee LC-III & 0.5 & $\$ 53$ & $\$ 39$ & $\$ 14$ & 3,154 & $\$ 715,647$ \\
\hline Okmulgee LC-III & 1.0 & $\$ 54$ & $\$ 30$ & $\$ 24$ & 5,139 & $\$ 1,773,843$ \\
\hline Pittsburg LC-III & 4.0 & $\$ 58$ & $\$ 13$ & $\$ 46$ & 5,938 & $\$ 3,056,363$ \\
\hline Seminole LC-III & 2.0 & $\$ 57$ & $\$ 26$ & $\$ 31$ & 2,242 & $\$ 898,225$ \\
\hline Wagoner LC-III & 1.0 & $\$ 55$ & $\$ 26$ & $\$ 29$ & 4,445 & $\$ 2,075,663$ \\
\hline Total & & & & & & $\$ 25,866,681$ \\
\hline
\end{tabular}


18 Table 6. Sensitivity analysis of the site-specific breakeven price $\mathrm{Mg}^{-1}$ of switchgrass.

\begin{tabular}{|c|c|c|c|}
\hline \multicolumn{4}{|l|}{ Internal Breakeven Price } \\
\hline & Land Class I & Land Class II & Land Class III \\
\hline Discount rates $4 \%$ & $\$ 51.47$ & $\$ 52.96$ & $\$ 55.76$ \\
\hline Discount rate double (8\%) & $\$ 53.63$ & $\$ 55.22$ & $\$ 57.86$ \\
\hline Wheat Price double & $\$ 107.65$ & $\$ 111.96$ & $\$ 118.41$ \\
\hline Land rent double & $\$ 55.64$ & $\$ 57.34$ & $\$ 59.92$ \\
\hline \multicolumn{4}{|c|}{ Internal and external breakeven price } \\
\hline Discount rates $4 \%$ & $\$ 30.45$ & $\$ 29.54$ & $\$ 22.87$ \\
\hline Discount rates double (8\%) & $\$ 29.91$ & $\$ 29.03$ & $\$ 22.40$ \\
\hline Wheat Price double & $\$ 88.28$ & $\$ 86.59$ & $\$ 85.58$ \\
\hline Land rent double & $\$ 34.58$ & $\$ 33.65$ & $\$ 27.09$ \\
\hline \multicolumn{4}{|c|}{ Differences between internal and internal plus external breakeven price } \\
\hline Discount rates $4 \%$ & $\$ 21.03$ & $\$ 23.41$ & $\$ 32.89$ \\
\hline Discount rates double ( $8 \%)$ & $\$ 23.72$ & $\$ 26.19$ & $\$ 35.46$ \\
\hline Wheat Price double & $\$ 19.37$ & $\$ 25.37$ & $\$ 32.83$ \\
\hline Land rent double & $\$ 21.06$ & $\$ 23.69$ & $\$ 32.83$ \\
\hline
\end{tabular}




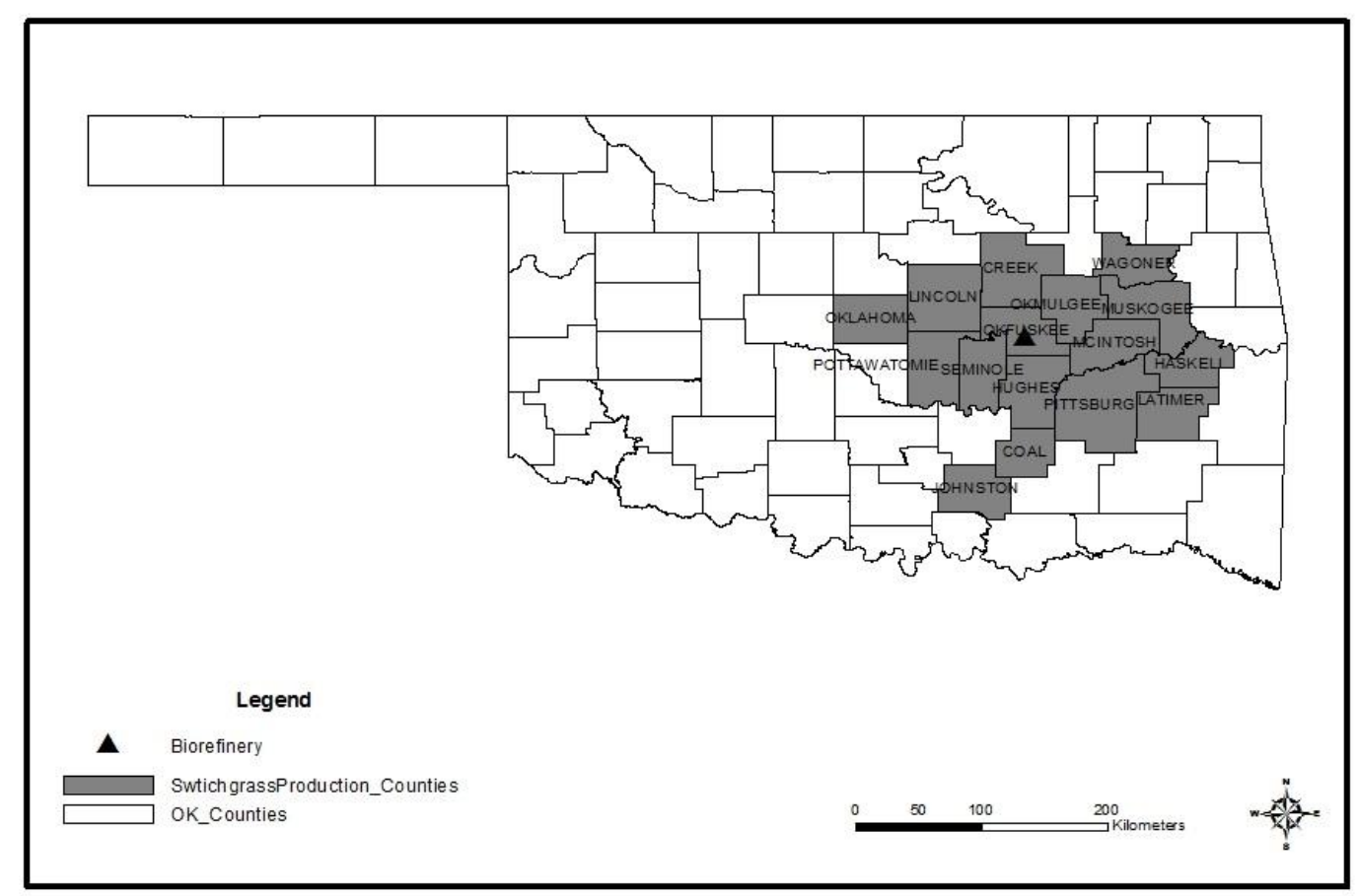

2

3 Figure 1. Land to be converted to switchgrass to support a hypothetical biorefinery at Okemah, 4 Oklahoma, USA. 
Soil

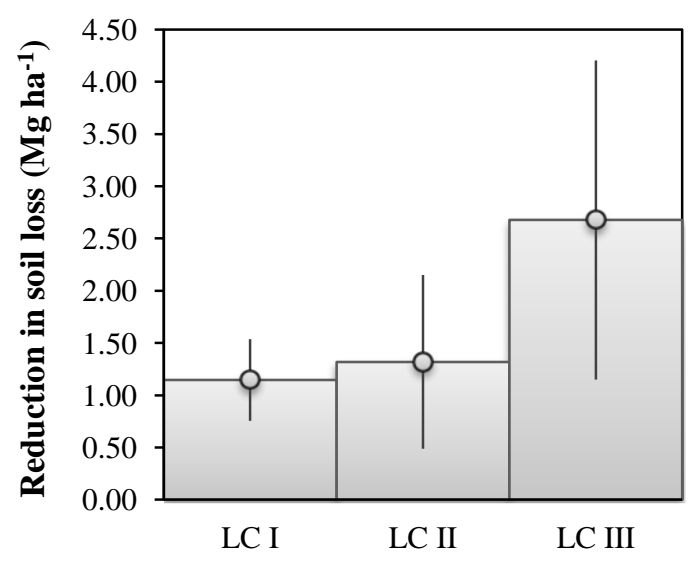

Nitrogen

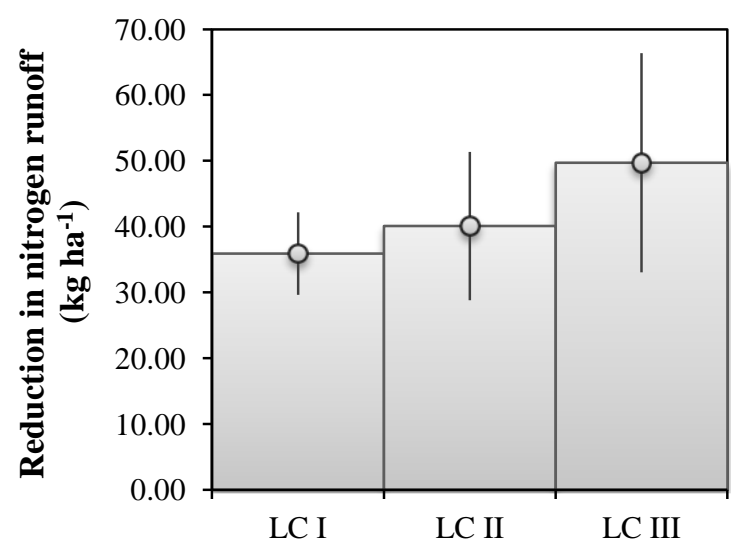

$-\circ-+/-1$ standard deviation from the average annual reduction in soil loss, nitrogen and phosphorous runoff, and SOC accumulation

Phosphorous

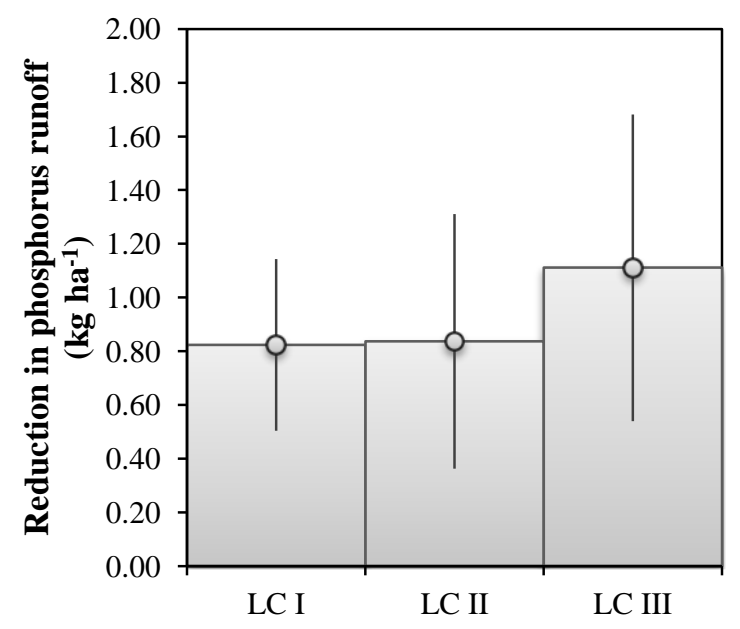

SOC

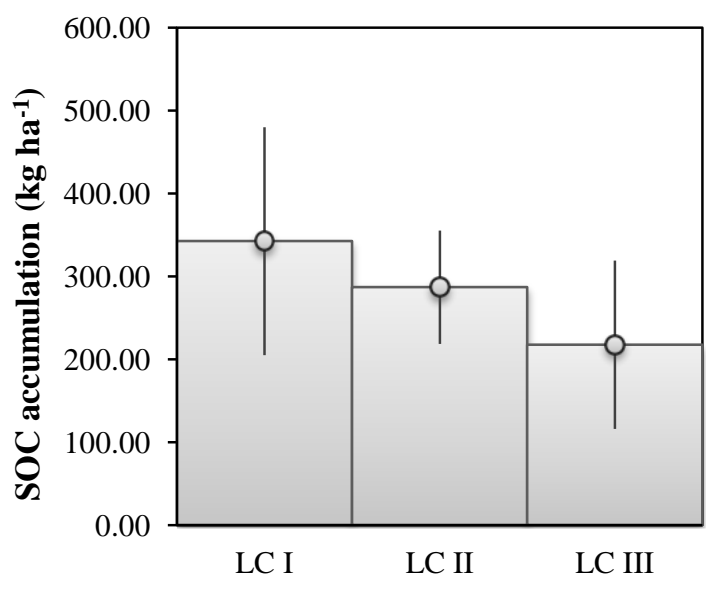

7

8

9

10

Figure 2. Average per year reduction in soil loss, nitrogen loss, phosphorous loss, and SOC accumulation between land class I (LC I), land class II (LC II), and land class III (LC III). 
11

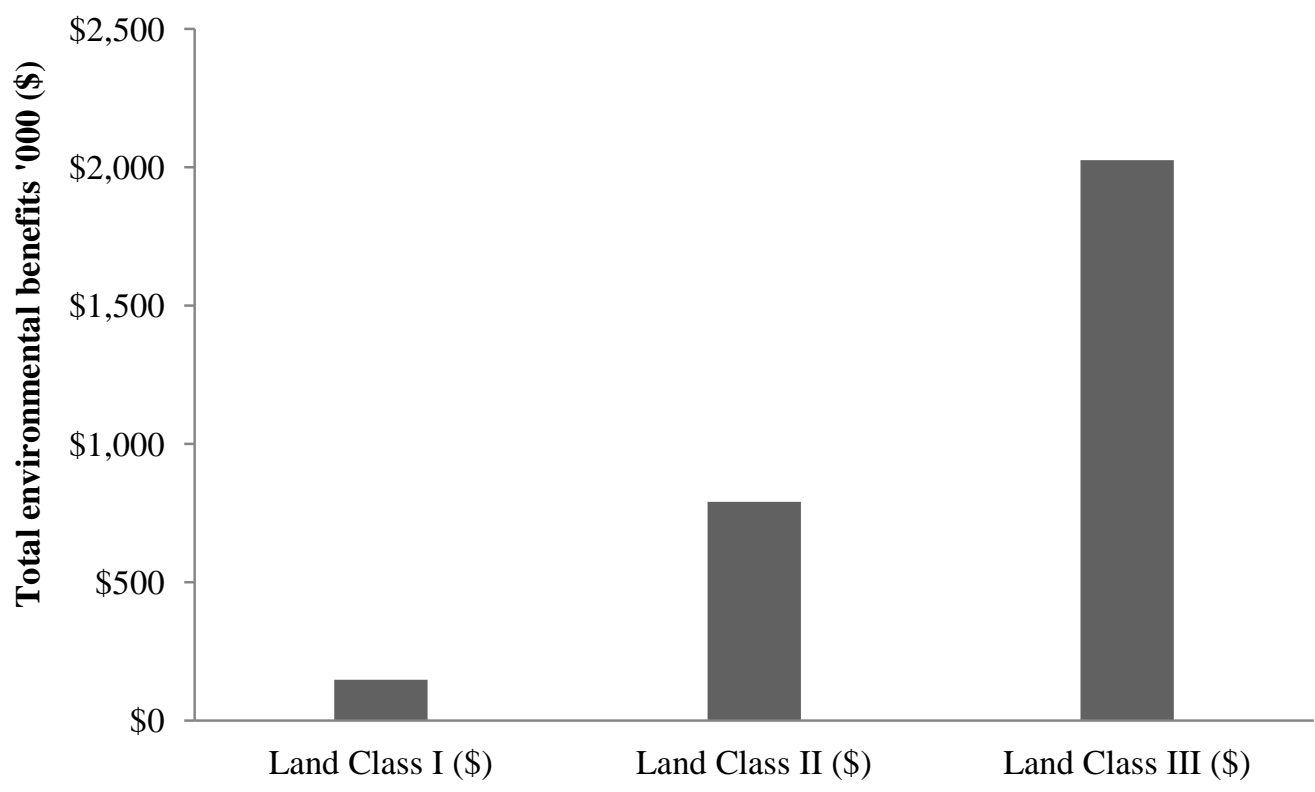

Figure 3. Average annual total environmental benefits derived to society from the establishment 14 of a hypothetical biorefinery requiring 700,000 $\mathrm{Mg} \mathrm{y}^{-1}$ of switchgrass feedstock obtained from 155,715 ha of land class I; 23,384 ha of land class II; and 36,283 ha of land class III.

16 